\title{
Pemahaman Peranan Pemasaran Islam Dalam Menghadapi Masa Pandemi Covid-19 Pada Pengusaha Muslim di Indonesia
}

\author{
Primasatria Edastama $^{1^{*}}$, Tatik Mariyanti ${ }^{2}$ \\ ${ }^{1}$ Fakultas Ekonomi dan Bisnis Univeristas Esa Unggul \\ ${ }^{2}$ Fakultas Ekonomi dan Bisnis Universitas Trisakti \\ *e-mail: primasatria@esaunggul.ac.id
}

\section{Informasi Artikel}

Diterima Redaksi : 26 Desember 2020

Revisi Akhir : 2 Januari 2021

Diterbitkan Online : 28 Januari 2021

Kata Kunci:

Covid-19, Pandemi, Produk, Pengusaha, Pemasaran Islam.

\begin{abstract}
Abstrak

Penelitian pada kegiatan pengabdian kepada
masyarakat (PKM) ini bertujuan untuk mensosialisasikan dan memberikan penyuluhan atas hasil penelitian dan pemahaman peranan pemasaran Islam dalam menghadapi masa pandemi Covid-19 pada pengusaha muslim di Indonesia. Metode yang digunakan adalah studi kepustakaan untuk menganalisis peranan pemasaran Islam dalam menghadapi masa pandemi Covid-19, dengan mengumpulkan literatur dan teori mengenai pemasaran Islam dan dianalisis keterkaitannya dengan masa pandemi Covid-19. Hasil dari studi ini adalah pemasaran Islam sangat dibutuhkan pada masa pandemi Covid-19 karena maraknya penawaran produk kesehatan dan produk lainnya yang sangat masive dan agresif, dengan menaikan harga yang tidak wajar disaat banyak permintaan akan produk kesehatan. Selanjutnya adalah mensosialisasikan hasil penelitian tersebut kepada pengusaha muslim di Indonesia dan dilihat pemahamannya melalui kegiatan pengabdian kepada masyarakat (PKM) menggunakan media daring. Pemahaman pengusaha muslim mengenai pemasaran Islam menjadi bertambah dan mendapat masukan serta wawasan dalam mengaplikasikan pemasaran Islam untuk berpromosi atau beriklan menawarkan produknya agar dapat bertahan pada masa pandemi Covid 19 ini.
\end{abstract}

produknya atau membeli produk dari tokonya.

Cara-cara yang dilakukan oleh para produsen atau penjual dalam memasarkan produk agar dapat menarik calon pelanggan terkadang membuat para calon pelanggan menjadi tidak nyaman, misalnya dengan menawarkan barang secara seporadis dan agresif, atau dengan cara-cara yang tidak sopan, menggunakan tenaga penjual yang siap menggoda calon pembeli yang berbeda lawan jenis. Ada juga dengan menawarkan barang yang tidak sesuai dengan kenyataannya. Menutupi kerusakan barang atau produk, memasarkan barang produk atau jasa dengan harga yang sangat tinggi atau tidak sewajarnya. Apalagi tren dari $e$ commerce pada saat ini menjadi solusi yang tepat dalam berbelanja dimasa pandemi Covid-19, dimana barang yang ditawarkan tidak dapat dipegang atau diraba, hanya dapat dilihat melalui video atau gambar, 
terkadang barang yang diterima tidak sesuai dengan gambar yang ditampilkan [2]. Hal tersebut membuat belanja e-commerce menjadi tidak nyaman tidak terpercaya dan akan berakibat pada transaksi penjualan sehingga hubungan antara penjual dan pembeli tidak terbentuk karena tidak adanya kepercayaan yang terbangun [3].

Perlu adanya pemasaran yang dapat membuat calon pelanggan tertarik dan merasa nyaman dengan barang, produk atau jasa yang ditawarkan. Pemasaran yang dapat membuat konsumen merasa nyaman untuk membeli produk atau barang dan pemasaran yang dapat meningkat kredibilitas merek dari produk atau barang yang ditawarkan. Penting bagi suatu pemasaran untuk dapat membangun kepercayaan bagi setiap calon pembeli atau konsumen untuk memilih dan menggunakan produk atau barang yang ditawarkan. Perlu adanya pemasaran yang menjunjung tinggi norma dan etika dalam menawarkan produk atau barang yang dijual. Apalagi bila dilihat dari penduduk Indonesia yang mayoritas muslim, penting sekali untuk memasarkan suatu produk, barang dan jasa sesuai dengan syariah Islam.

Pemasaran yang dapat menghadapi masa pandemi Covid-19, agar suatu produk, barang atau jasa yang ditawarkan tetap diminati oleh konsumen dan menarik calon konsumen baru serta menjadikan konsumen menjadi loyal terhadap produk, barang dan jasa tersebut, sehingga pada akhirnya akan menaikan keuntungan dan bisnisnya tetap bertahan dalam masa pandemin Covid-19 ini.

\section{METODE}

Penelitian ini dilakukan dengan studi pustaka dan dianalisis secara deskriptif dan hasilnya disosialisasikan kepada para pengusaha di Indonesia melalui kegiatan PKM yang dilaksanakan melalui media daring. Metode yang digunakan adalah analisis deskriptif dengan studi pustaka yang dilakukan dengan mengumpulkan data-data seperti penelitan terdahulu dan teori-teori yang ada [4]. Teori dan penelitian terdahulu yang terkait dengan marketing Islam. Setelah proses pengumpulan data dilakukan lalu dianalisis secara diskriptif dengan masalah yang ada yaitu dimana adanya krisis ekonomi yang diakibatkan oleh pandemi Covid-19 dan peranan marketing Islam dalam hal tersebut. Kegiatan PKM yang dilakukan untuk melihat pemahaman marketing Islam pada pengusaha muslim di Indonesia dengan memberikan penyuluhan, sosialisasi dan pemaparan langsung kepada para audiens pengusaha muslim. Peneliti yang sekaligus nara sumber dari kegiatan PKM ini juga melakukan pemaparan, diskusi dan evaluasi terhadap para audiens sehingga dapat mengetahui langsung sejauh mana dapat memahami peranan marketing Islam dalam menghadapi pandemi Covid-19 terkait dengan hasil penelitian yang telah dilakukan.

\section{HASIL DAN PEMBAHASAN}

Pada perspektif pemasaran Islam, produk yang dijual perusahaan harus sepenuhnya halal. Semua input, proses dan output harus sesuai dengan syariah yaitu produk yang dibuat, pengiriman dan konsumsi harus ramah lingkungan dan sama sekali tidak berbahaya, karena Islam dengan jelas melarang menyebabkan kerusakan pada apapun yang diciptakan Tuhan, Pemasaran Islam memadukan agama, etika, dan dunia bisnis. Pemasaran Islam pada intinya adalah prinsip kejujuran dan etika [5]. Hendaknya dalam berproduksi dan memasarkan suatu produk apalagi produk kesehatan seperti sekarang ini dimasa pandemi Covid-19, perlu memperhatikan kehalalannya dan itu menjadi yang utama, seperti pembuatan vaksin, obat Covid-19 misalnya.

Iklan makanan halal tidak boleh menyesatkan atau bertentangan dengan prinsip hukum Islam, misalnya dengan menampilkan elemen yang tidak sopan, harus dihindari. Penafsiran halal yang sejalan dengan etika Quran dan contoh kenabian untuk mengatur dunia Islam melalui model dan pemasaran halal, mengharuskan muslim untuk menolak pemasaran yang konsumerisme [6]. Iklan obat-obatan, iklan masker dan iklan alat kesehatan atau iklan produk lainnya hendaknya menampilkan dan memperhatikan kesopanan dan tidak menyinggung ras, karena hal tersebut sangat penting dalam kehidupan kerukunan 
antar manusia, terlebih lagi pada masa pandemi ini.

Sistem pemasaran yang sesungguhnya bagi umat manusia adalah sejalan dengan ajaran Islam, yang akan menjadi model bagi masyarakat, karena sistem pemasaran menjadi lebih baik lagi [7]. Pemasaran Islam sejalan dengan ajaran Islam yaitu Islam yang rahmatan lil alamin atau Islam untuk seluruh umat, dimana pemasaran Islam sangat memperhatikan etika, norma, dan kebermanfaatan suatu produk atau jasa yang ditawarkan dengan jelas, transparan dan halal untuk kenyamanan dalam menggunakan produknya.

Syariah berarti adalah jalan yang lurus dan dianggap oleh muslim sebagai pedoman Tuhan untuk perilaku manusia. Hidup adalah perjalanan yang menghadirkan banyak jalan bagi setiap orang, tetapi hanya satu dari jalan itu yang jelas dan lurus, dan jalan ini disebut syariah. Hukum syariah berasal dari kombinasi berbagai sumber, termasuk Quran dan Hadits serta fatwa atau aturan ulama. Semua bentuk aktivitas sosial, ekonomi, dan politik diatur oleh hukum Syariah, sehingga aktivitas branding dan pemasaran juga harus diatur dalam hukum syariah [8]. Hendaknya dalam branding dan promosi suatu produk memperhatikan hukum syariah, dimana merek suatu dagang atau produk dan jasa disesuaikan juga dengan norma dan etika yang ada dimasyarakat.

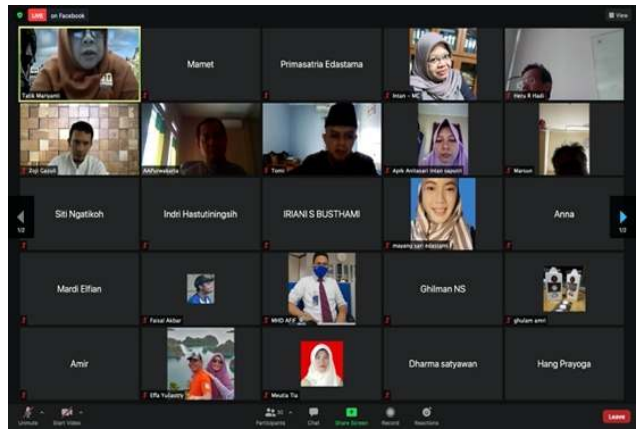

Gambar 1. PKM Pemahaman Peranan Pemasaran Islam

Islam juga merepresentasikan budaya dan cara hidup karena yang terdapat dalam Quran atau Sunnah berdampak langsung pada perilaku, baik dalam praktik seharihari seperti sholat atau pergi haji ke Mekkah. Dalam hal itu, dampak pada pemasaran sangat kuat karena beberapa produk, layanan, atau perilaku dilarang, wajib, sangat direkomendasikan, atau diizinkan. Kedua sumber ini membentuk syariah, hukum sakral yang harus dipatuhi oleh umat Islam [9]. Pemasaran Islam adalah cerminan dari mempresentasikan cara hidup yang ada dalam Quran dan Hadist, seperti perilaku sehari-hari, dimana ada yang dibolehkan, wajib dan yang dilarang.

Penelitian terdahulu banyak yang bertajuk mengenai pentingnya pemasaran Islam dimana perlu adanya pengintegrasian antara pemasaran Islam dengan pemasaran kontemporer sehingga menghasilkan suatu perspektif baru dalam bidang pemasaran, karena Islam memandang bahwa kegiatan ekonomi adalah kegiatan yang vital bagi kehidupan umat manusia. Pemasaran Islam adalah bagian dari kegiatan ekonomi dan bisnis yang sudah ada petunjuknya dalam Quran dan Hadist [10].

Masih ada praktik pemasaran lembaga keuangan Islam saat ini yang tidak sepenuhnya sejalan dengan tujuan syariah, terutama pada produk keuangan Islam yang lebih mahal daripada produk konvensional. Masih ada kegiatan promosi yang tidak sejalan dengan ketentuan syariah, gaya pemasaran konvensional masih ditemukan dalam menawarkan produk keuangan Islam. Pemasaran Islam dalam menawarkan produk keuangan Islam harus benar-benar sesuai dengan pertimbangan ketuhanan, hukum, dan etika syariah, hal ini akan membuat Lembaga keuangan Islam lebih menarik dan sama-sama bermanfaat bagi semua umat manusia tanpa memandang agama seperti yang diyakini syariat dalam budaya sosial, ekonomi dan keuangan untuk semua umat manusia [11].

Penggabungan pemasaran sosial dan pemasaran Islam membuahkan disiplin ilmu baru yaitu pemasaran sosial Islam, dimana pemasaran sosial yang ada untuk kepentingan kesejahteraan masyarakat atau yang membutuhkannya seperti kampanye atau promosi kesehatan, kebutuhan hidup dan perlindungan kehidupan masyarakat, itu semua hendaknya sejalan dengan pemasaran Islam yang berbasis syariah [12]. Seperti pada masa saat pandemi ini, memasarkan produk apapun hendaknya memperhatikan terutama adalah harga, 
karena krisis ekonomi yang terjadi instumen harga jual menjadi sangat penting, karena dalam mengeluarkan uang untuk membeli barang sangat diperhatikan karena masih banyak kebutuhan lain yang harus dibeli atau dipenuhi. Produk kesehatan saat ini banyak dibutuhkan sehingga permintaan bertambah, hendaknya produsen tidak menaikan harga sepihak, pemasaran sosial Islam dapat membantu hal ini karena berpromosi atau beriklan untuk suatu kebutuhan sosial dan bertujuan untuk kesehatan dengan harga terjangkau dan kesehatan masayarakat akan tercapai.

Hasil penelitian menunjukkan bahwa pemasaran Islam memiliki pengaruh yang signifikan terhadap karakteristik konsumen muslim dan oleh karena itu mempengaruhi pilihan utama mereka tentang produk dan layanan tertentu [13]. Konsumen muslim merasa nyaman dan percaya pada produkproduk yang ditawarkan atau dipromosikan dengan cara-cara pemasaran Islam, kepercayaan dikalangan konsumen muslim akan terbentuk dan minat untuk membeli produk, barang atau jasa semakin besar dan dapat menjadi konsumen tatap, bahkan akan memberikan ulasan yang positif sehingga dapat memberikan keuntungan bagi produsen dan penjual.

pada penelitian terdahulu dimana industri farmasi di Yaman menggunakan pemasaran Islam dalam mempromosikan produknya karena perusahaan farmasi banyak yang tidak etis dengan menaikan harga pada biaya perawatan kesehatan sehingga tidak dipercaya, namun dengan menggunakan pemasaran Islam dengan meningkatkan kredibilitas dari merek untuk produk farmasinya [14].

\section{KESIMPULAN}

Peranan pemasaran Islam dalam masa pandemi Covid-19 ini sangat diperlukan, karena banyak sekali produk-produk kesehatan dan produk lainnya yang ditawarkan kepada masyarakat dengan harga yang tinggi dan tidak wajar, memanfaatkan situasi dan kondisi dimana produk kesehatan sekarang ini banyak dicari dan dibutuhkan sehingga permintaan menjadi meningkat. Meningkatnya permintaan akan barang, produk dan jasa hal ini dilihat oleh penjual dan produsen kesempatan untuk mengambil keuntungan yang besar, namun hal itu sangat tidak etis dan bertentangan dengan syariah, dimana banyak orang yang kesusahan namun mengambil keuntungan dari kondisi yang serba tidak menentu akibat adanya pandemi Covid-19 ini. Peranan pemasaran Islam dapat meningkatkan kepercayaan pada konsumen dan meningkatkan kredibilitas merek pada produk, barang atau jasa.

Pemahaman peranan pemasaran Islam pada pengusaha muslim di Indonesia juga semakin meningkat karena mengikuti program kegiatan pengabdian kepada masyarakat (PKM) ini. Diskusi dan tanya jawab yang berlangsung pada saat pemaparan menjadi indikasi bahwa kegiatan PKM ini memang manarik dan sangat dibutuhkan. Wawasan keilmuan dan masukan yang didapat dari kegiatan ini sangat berarti dan dapat langsung di implementasikan pada kehidupan bisnisnya, agar dapat tetap bertahan dalam menghadapi masa pandemi ini.

\section{SARAN}

Pada masa yang akan datang hasil penelitian hendaknya langsung dapat disosialisasikan lewat kegiatan PKM seperti ini dan nantinya dapat langsung diimplementasikan di masyarakat, sehingga tridarma perguruan tingg dapat tepat sasaran dan berdaya guna untuk masyarakat, bangsa dan negara.

\section{UCAPAN TERIMA KASIH}

Ucapan terima kasih kepada semua pihak yang membantu dalam kelancaran kegiatan PKM ini, terutama pada Fakultas ekonomi dan bisnis Universitas Esa Unggul dan Universitas Trisakti.

\section{REFERENSI}

[1] Di Gennaro, F., Pizzol, D., Marotta, C., Antunes, M., Racalbuto, V., Veronese, N., \& Smith, L. (2020). Coronavirus diseases (COVID-19) current status and future perspectives: A narrative review. International Journal of Environmental Research and Public Health, 17(8).

[2] Leong, L.-Y., Hew, T.-S., Ooi, K.-B., Chong, A. Y.-L., \& Lee, V.-H. (2020). Understanding trust in ms-commerce: 
The roles of reported experience, linguistic style, profile photo, emotional, and cognitive trust. Information \& Management.

[3] Stouthuysen, K. (2020). A 2020 perspective on "The building of online trust in e-business relationships." Electronic Commerce Research and Applications, 40,

[4] Merriam, S. B., \& Tisdell, E. J. (2015). Qualitative Research: A Guide to Design and Implementation. Wiley.

[5] Alserhan, B. A. (2020). The Principles of Islamic Marketing (2nd ed.). Taylor $\&$ Francis.

[6] Armanios, F., \& Ergene, B. A. (2018). Halal Food: A History. Oxford University Press.

[7] Billah, M. M. (2017). Islamic Economies: Stability, Markets and Endowments (N. Alam \& S. A. R. Rizvi (eds.)). Springer International Publishing.

[8] Temporal, P. (2011). Islamic Branding and Marketing: Creating A Global Islamic Business. Wiley.

[9] Nestorović, Č. (2016). Islamic Marketing: Understanding the SocioEconomic, Cultural, and Politico-Legal Environment. Springer International Publishing.

[10] Hashim, N., \& Hamzah, M. I. (2014). 7P's: A Literature Review of Islamic Marketing and Contemporary Marketing Mix. Procedia - Social and Behavioral Sciences, 130, 155-159.

[11] Aman, A. (2019). Islamic marketing ethics for Islamic financial institutions. International Journal of Ethics and Systems, 36(1), 1-11

[12] Hasan, M. (2019). Social marketing: an Islamic perspective. Journal of Islamic Marketing, 11(4), 863-881.

[13] Floren, J., Rasul, T., \& Gani, A. (2019). Islamic marketing and consumer behaviour: a systematic literature review. Journal of Islamic Marketing, 11(6), 1557-1578.

[14] Al-Nashmi, M. M., \& Almamary, A. A. (2017). The relationship between Islamic marketing ethics and brand credibility: A case of pharmaceutical industry in Yemen. Journal of Islamic Marketing, 8(2), 261-288. 